\title{
Valuation of Start-ups: A Behavioral and Strategic Perspective ${ }^{1}$ Samuel Mongrut \\ EGADE Business School, Tecnológico de Monterrey, México Universidad del Pacífico, Lima, Perú \\ Nidia Juárez \\ Tecnológico de Monterrey, México \\ (Recibido 13 de agosto 2017 , aceptado 29 de enero 2018.) DOI: http://dx.doi.org/10.21919/remef.v13i3.314
}

\begin{abstract}
The aim of this research is to propose a methodology for the valuation of start-ups, incorporating prospective and behavioral factors with traditional risk analysis. The proposed methodology is useful for the entrepreneur to undertake their new business with their own capital as well as in the case that angel investors are involved. The main finding is that it is possible to build a consistent methodology that makes entrepreneurs conscious of their cognitive biases, allowing them to value the business idea with a multidimensional approach. It is important to consider that the values assigned to the parameters of the critical variables, by scenario, must be feasible and reasonable, since otherwise it could fall into a possibility of unattainable results. The resulting methodology represents an alternative that integrates motivational and strategic aspects, becoming a useful tool in the decision-making process of the entrepreneur as well as for angel investors, bridging the gap between their valuations.
\end{abstract}

JEL Classification: L26, L29.

Keywords: Entrepreneurship, behavioral finance.

\section{Valoración de emprendimientos: una perspectiva estratégica y conductual.}

\section{Resumen}

El objetivo de la presente investigación es proponer una metodología para la valoración de nuevos emprendimientos integrando factores prospectivos y conductuales con el análisis de riesgo tradicional. La metodología propuesta es de utilidad para el emprendedor al momento de decidir emprender un nuevo negocio tanto con recursos propios como en el caso en el que involucra inversionistas ángeles. La principal contribución es la construcción de una metodología que permite que los emprendedores sean conscientes de sus sesgos cognitivos, permitiéndole evaluar la idea de negocio con un enfoque multidimensional. Es importante considerar que los valores asignados a los parámetros de las variables críticas, por escenario, deben ser factibles y razonables, ya que de lo contrario se podría caer en una posibilidad de resultado inalcanzable. La metodología resultante representa una alternativa que integra aspectos motivacionales y estratégicos, convirtiéndose en una herramienta útil en el proceso de toma de decisión del emprendedor así como en el de los inversionistas ángeles, cerrando la brecha de valoración que se presenta entre ellos.

Clasificación JEL: L26, L29.

\footnotetext{
${ }^{1}$ Correspondence: Prof. Samuel Mongrut, Instituto Tecnológico y de Estudios Superiores de Monterrey, Av. Epigmenio González 500, Fracc. San Pablo, Telf: +524421816378, Email: smongrut@itesm.mx
} 
Palabras claves: Emprendimiento, finanzas conductuales.

\section{Introduction}

One of the biggest challenges for the entrepreneur is the strategic evaluation of his business ideas, which consists of anticipating different strategies that might be adopted to face the various scenarios that are possible during the firm's startup phase. The whole process requires the entrepreneur to clearly know its motivations to launch a business, to be conscious of his own cognitive biases, to have a good domain of multidimensional thinking and to decide to set up a business idea based on the opportunity and accuracy of the strategies proposed for each scenario and not only on positive profitability index forecasts. This way the entrepreneur increases the probability of success of his business thanks to the robustness of his strategies, which allows him improve the benefits and/or minimize the losses, depending on the scenario considered.

In spite of the importance of this challenge for the entrepreneur, most of the time he does not face it due to the myopic valuation paradigm, which is present even in the business incubation processes. The paradigm, in the best-case scenario, translates in assessing the business idea in a risky environment only by analyzing the behavior of comparable companies that are listed in stock markets, without taking into account the entrepreneur's motivations, his cognition biases and the business' own risk. This leads entrepreneurs to start businesses underestimating the risks and using only unidimensional thinking, i.e. considering only the strategies linked to the scenarios that they consider are the most probable or expected, a behavior that sometimes culminates with a failure.

Unfortunately, the myopic valuation paradigm, which looks for encountering the value the business ideas would have if it were listed in the stock market, seems to be prevalent. This obsession comes from corporate finance and carries to inadequate assumptions. For instance, that the entrepreneur has a diversified portfolio, that he is starting the business with the aim of selling it in the future and/or that the economic risk of comparable companies is the same of that of the new one only because they operate in the same industry or sector.

The truth is that entrepreneurs can dispose of a low amount of resources and, when they start a business, they generally can count only on their own savings and not on the help of angel investors or venture capital, at least at the beginning. According to the National Institute of Statistics and Geography (INEGI, by its Spanish name), in 2014 only $10.8 \%$ of microenterprises financed itself through credits and/or private equity (INEGI, 2014).

On the other side, the myopic valuation paradigm does not consider the riskaversion of the entrepreneur, its motivations or even its cognitive biases that might be responsible of pushing him to undertake excessive risks. Motivations can include monetary as well as non-monetary gains; therefore, non-monetary benefits (for instance, to provide a job to an unemployed member of the family) must be taken into account when considering the different scenarios. Likewise, 
the overconfidence can lead the entrepreneur to undertake excessive risks due to forecasting mainly positive results (over-optimism bias), to generalize from few and insufficient evidence (representativeness bias) and/or to have an excess of confidence in his own abilities, resources and knowledge that goes beyond the reality (illusion of control bias).

Motivational factors are created thanks to the influence of environmental features and to the own individual's personality (Audretsch and Keilbach, 2008). The first researches classify them into "pull" and "push". "Pull" factors originates from the identification of business opportunities from the market, while "push" factors are related to the personal needs of the entrepreneur (Shinnar and Young, 2008). Therefore, motivational factors help to identify if the venture comes from opportunities ("pull" factors) or necessities ("push" factors).

Similarly, the literature offers studies about the risk tolerance of entrepreneurs, where it has been proved that entrepreneurs do not have a lower riskaversion compared to other groups of individuals (Busenitz and Barney, 1997; Brockhaus, 1980). However, there is evidence that entrepreneurs have a tendency of underestimating risk, due to the overconfidence and to the other behavioral biases that follows from it (Kahneman and Lovallo, 1993).

Cognitive biases allow the entrepreneur to deal with uncertainty, with the information overload and with the fear of starting a business. Nevertheless, they affect the decision making process and brings him to take excessive risks and, therefore, to commit mistakes that could have been avoided if he were aware of his own biases (Forbes D.P., 2005 Simon, Aughton and Aquino, 1999). Due to the lack of (multidimensional) strategic valuation methodologies that can integrate behavioral factors (motivational and cognitive), the present research represents a relevant contribution to the actual literature since it combines behavioral, financial and strategic factors. Moreover, it highlights entrepreneur's biases and their possible impact on the required return, on the expected business value and on the strategies considered in the scenarios' analysis.

The following work is organized as described: the next section explains the motivational factors that lead the entrepreneur to the decision of starting a new business, as well as the cognitive biases he can possibly face when dealing with uncertainty and risk. Section 3 presents the multidimensional or strategic vision and compares it to the unidimensional or static one. Section 4 exposes the methodology proposed to value new businesses, while section 5 shows a practical application of it. The last section concludes the study.

\section{Motivational factors and cognitive biases in the entrepreneur}

\subsection{Motivational factors}

In the entrepreneurial literature, two big groups of factors are generally considered responsible of motivating the individual to start a new business. The first group includes external factors such as the characteristics of the environment and the context where the individual operates ("pull" factors). According to Audretsch and Keilbach (2008), being in an environment characterized by an 
inclination of starting new activities stimulates the occurrence of emulations, creating a favorable climate for the development of new companies. The second group focuses on factors that are typical of the individual, among which sociodemographic, psychological and perceptional ones ("push" factors) (Minniti and Nardone, 2007). Busenitz and Lau (1996) propose a conceptual model where all of these factors appear and are classified as social, cultural and personal.

Following Bonnet, Brau and Cussy (2008), there are two main motivations that bring the entrepreneur to start a new business: necessity and opportunity. Necessity happens when the individual is facing an unemployment situation or is not satisfied about his current job; opportunity happens when the person is able to recognize a business opportunity in the market and to transform his idea into an innovative project.

Barba-Sánchez and Atienza-Sahuquillo (2012) develop a model to define the motivational circumstances that can affect the decision-making process, through the empirical study of 101 entrepreneurs that own companies with less than one year of life. They encounter that their motivations are the seek for: 1) personal realization and success; 2) economical and professional independence; 3) personal autonomy; 4) sense of belonging and institutional influence; 5) continuity (for instance, continuing a familiar tradition); 6) social and personal power; 7) sharing. Starting from these results, entrepreneurs have been divided into five groups: self-employed, ambitious, self-satisfied in the family firm, challenge-lover and altruistic and competent.

Several researches have been made to determine the reasons that move entrepreneurs in different countries and industries. Among them, Chen and Elston (2013), from the analysis of 254 little restaurants in China, propose a threefactor model which includes microenvironment, personal and psychological factors. The former includes the political, cultural and social impact, the economic situation, the competition and demographic aspects. The personal factors include specific characteristics of the individual such as age, education, personality, self-perception and values; while psychological factors takes into account motivations, beliefs, attitude and risk aversion, among others. All the three dimensions must be considered when valuing any business.

Espiritu-Olmos and Sastre-Castillo (2015) study a sample of 1210 students of public universities, with the aim of identifying the determinants of the entrepreneurial spirit. They account for socioeconomic, educational and psychological elements and find out that the gender is a highly significant determinant, being the entrepreneurial mindset more present in males than in females. Regarding education, the more advanced the academic preparation, the less the desire to start a business. Finally, the most important variable among the personal factors has been the personal growth, which is related to authority and achievements.

Jaimes, Millan and Perez (2017) conducted a researchresearch studying sociodemographic, psychological and socioeconomic factors of 342 students in Mexico, finding that the sociodemographic factors that affect the students' entrepreneurial intention are age, marital status, semester and knowledge of the 
Entrepreneur Program; the psychological factors are self-esteem, innovation and risk-proneness; and as a socioeconomic factor, the investment trend. Similarly, Fernandez, Miriam, Nina, Dante and De la Cruz Fernandez (2017) conducted a study with 50 entrepreneurs in Ecuador, they concluded that entrepreneurship in rural environments is conditioned by social factors related to education and training, and with the skills to create a new company, social and cultural norms, the perception of opportunities and the motivation to undertake. In 2017, BarbaSanchez and Atienza- Sahuquillo concluded that new businesses are created not only by those with abilities and aptitudes to start a new Enterprise, but also by those with the motivation to do so.

The key-conclusion is that, when evaluating ventures, the results are strictly linked to the motivations so that it is indispensable to take them into account. For instance, if an entrepreneur is motivated by social needs and personal power, it is important to verify that the launch of the business will also include nonmonetary benefits, such has the support of his family, which would strengthen its necessity as well as provide monetary benefits.

\subsection{Cognitive biases}

Cognitive biases work as defense mechanisms in the decision-making process when the individual faces a high degree of uncertainty. These biases occur more frequently in entrepreneurs, due to the environment full of uncertainty and to the lack, in quantity and quality, of information.

Palich and Bagby (1995) affirm that the decision making process of creating a new business can be explained more by the entrepreneur's perception of the risk than by his real degree of risk-aversion. Subsequently, it is interesting to see which biases affect the entrepreneur's risk-perception.

Busenitz and Lau (1996) define cognitive biases as subjective opinion coming from heuristic processes and that are especially present in entrepreneurs, which become less rational when taking decisions. They realize a study comparing 124 entrepreneurs and 95 managers of big companies, in order to identify the differences in their decision-making process and in the impact of biases (Busenitz and Lau, 1997). Findings are that entrepreneurs are more affected by biases than managers - especially overconfidence and representativeness biases - normally due to the lack of pre-defined processes and structures and of historic information that might help deciding, therefore, they are more prone to underestimate risks.

Simon, Houghton and Aquino (1999) confirm that cognitive biases influence the perception of the risk of the person willing to start a new business. They analyze the overconfidence, the illusion of control and the representativeness biases on a group of 191 master students, finding that cognitive biases lead the individual to perceive different levels of risk and that those students that perceive less risk are more inclined to start a business since their risk-tolerance level does not affect their decision. 
In 2007, Koellinger, Minniti and Schade realize a study starting from the survey that the Global Entrepreneurship Monitor (GEM) made in 2001 in 18 countries. They evidence that the perception entrepreneurs have is, in most of the cases, subjective and full of biases, especially in what concerns the factors considered fundamental in the decision-making process. Among them, they analyze the awareness of new business opportunities, the specific knowledge and skills of the entrepreneur and the risk-perception.

Gudmundsson and Lechner (2013) study the effect of the overconfidence and the over-optimism biases on the survival rate of 115 Icelandic companies of which 70 survived and 45 faced bankruptcy. The most interesting findings are that the overconfidence plays a central role in the bankruptcy and that the situation get worse when the overconfidence is combined with other biases.

According to Baron, Mueller and Wolfe (2016), entrepreneurs present high values of self-efficiency perception, a bias that is related to overconfidence and that implies they trust too much in their own abilities, which carry them to set unrealistic goals. Peterson, Mueller and Sequeira (2009) measure the selfefficiency perception of 167 entrepreneurs, using a measure created by McGee (2009) and find out it is highly correlated with the level of difficulty of the objectives that are established. The authors, therefore, suggest that a way to minimize the effects of the bias on the choice of unrealistic goals is to practice auto control. In this sense, Acosta-Veliz, Villacís-Aveiga and Jiménez-Cercado (2017) found in a group of 500 university students that perceived self-efficiency is an indicator of entrepreneurial intention.

In 2017, Zhang and Cueto found in the literature of entrepreneurship, 11 cognitive biases that explain the phenomenon of entrepreneurship, including: overconfidence, optimism, self-serving attributions illusion of control, the law of small numbers, similarity, availability, representativeness, status quo, planning fallacy and escalation commitment.

The key-aspect of the cognitive biases is that the entrepreneur should be aware of which biases he has so that he can identify which variables might affect the valuation of the new venture and what it would be its bias-free value. According to Nouri, Imanipour, Talebi, y Zali (2017), reducing negative effects of these biases and enhancing their positive effects could definitely influence the creation, survival and growth of entrepreneurial ventures.

\section{Multidimensional versus unidimensional}

One of the most important points in the valuation of ventures is its multidimensionality because here is where the strategic component lays. Usually, the analysis of traditional risk is the one used in the business valuation, consisting in calculating the expected value of the profitability indexes, notoriously the Net Present value (NPV). The most advanced studies do a sensibility analysis of the NPV in case of different discount rates and formulate a NPV distribution of probability. 
Unfortunately, the NPV distribution does not have any financial interpretation unless the NPV has been calculated with a discount rate proportionate to the free cash flow risk. This is the common drawback of the investment projects' risk analysis.

Moreover, researches generally implicitly assume that the most important critical variable of the project is listed in a stock or commodities market and that its risk controls the project risk. For instance, the risk of an oil exploitation project is the same risk that the price of the oil barrel has. This assumption guides the entrepreneur not only to a myopic valuation but also to value the operational flexibility of the project using sophisticated models of real options. Nevertheless, in case of entrepreneurship, for definition the critical variables are not public but private and, therefore, there are not public markets than can gather their values.

Finally yet importantly, most of the valuations are made in risky conditions and reach the expected NPV - whose probability of occurrence is null - without elaborating any strategy for this expected scenario: this is the unidimensional focus.

Since the future cannot be predicted, this paper suggests a multidimensional focus where several scenarios are considered. The environment variables that cannot be influenced help to define the scenarios and, inside of each of them, the project risk is estimated for each future year based on the risk of the business critical variables. The non-critical variables are treated as if they were certain.

The multidimensional focus implies the proposal of contingence's strategies for each scenario, so that if one of them happens it will be clear how to act to improve the gains and/or to minimize the losses. This is what makes an investment proposal robust and irrefutable. In this sense the profitability indexes only indicate a range of how much it would be possible to gain or to loose, but they do not constitute investment decision criteria. It is under this strategic framework that the present article details the valuation methodology.

\section{Proposed methodology for the valuation of new businesses}

Figure 1 displays the different circumstances an investor can face: if he does not possess the required economic resources, he will not start a business. If the entrepreneur has the economic resources, it can still happen that he decides not to start a business due to a lack of alignment between his motivation and the business opportunity. If he decides to start a business, it might be ex-ante, when the decision is taken before making a proper analysis or an evaluation of the necessary investment or, otherwise, ex post, in the opposite case. 
Figure 1: The decision to start a business

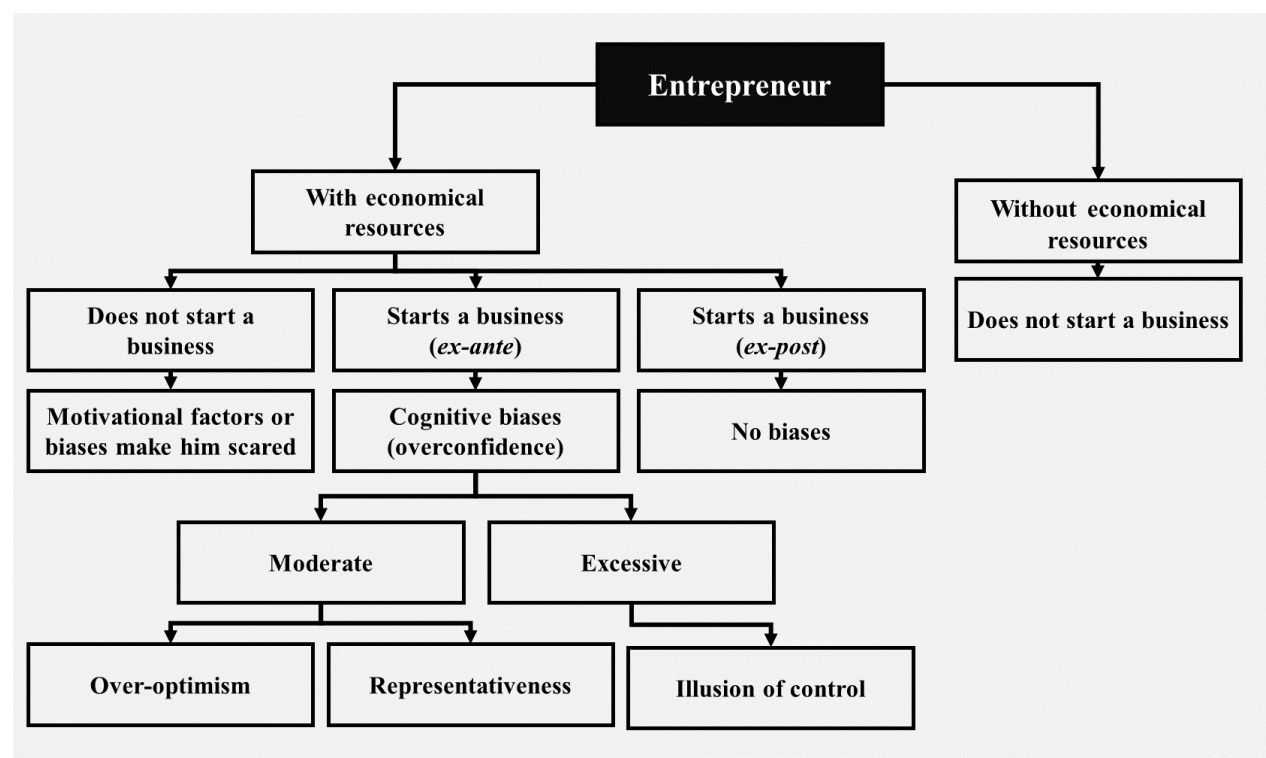

Source: Own elaboration

The entrepreneur might opt for the ex-ante form, meaning he avoids making an analysis or an evaluation of the business opportunity because of the presence of cognitive biases such as overconfidence. Overconfidence might be moderate, in the case of over-optimism and/or representativeness or it can be excessive, translating in the illusion of control. If the entrepreneur prefers the ex post form, applying the methodology suggested below, it is assumed that he is aware of his own biases and that, therefore, they will not influence his decisions.

The methodology illustrated is a hybrid model that can be used by both the entrepreneur and the investor angel or venture capital, helping to reduce the valuation gap between them. As shown by Figure 2, it is articulated into seven phases. 
Figure 2: Behavioral and strategic methodology to assess new ventures

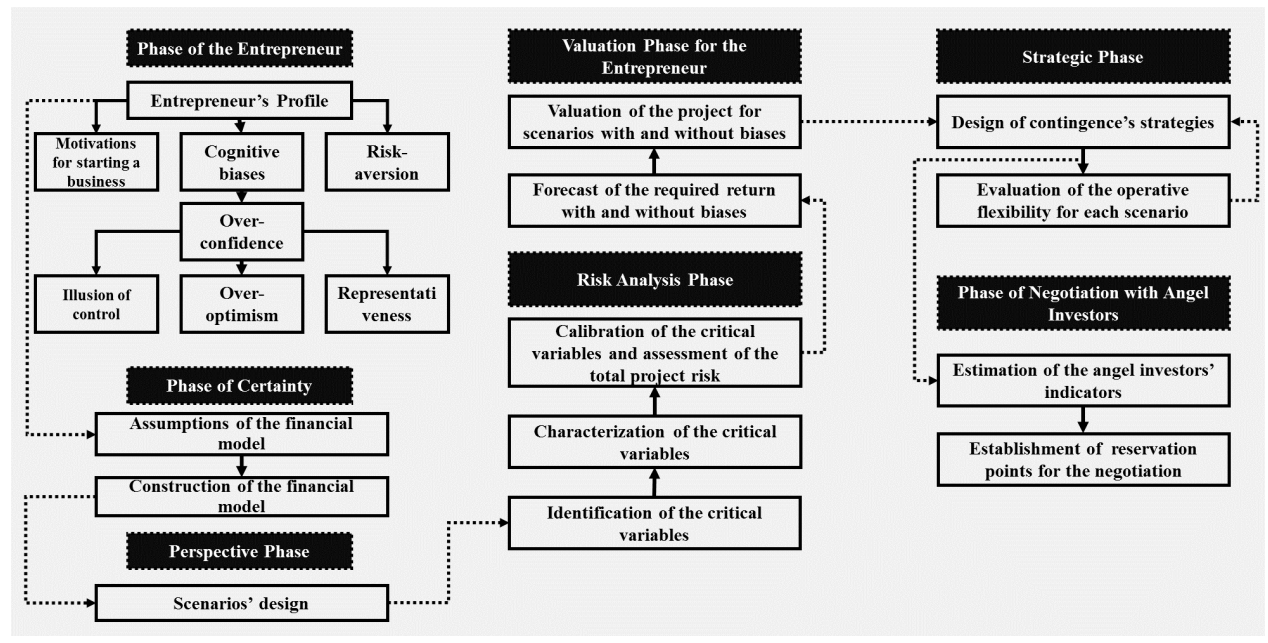

Source: Own elaboration

During the phase of the entrepreneur, his profile is defined starting from a series of individual surveys. The motivations that brought the entrepreneur to the decision of starting the business are analyzed; it is defined whether he presents the overconfidence bias and, if so, which variety (illusion of control, overconfidence and representativeness) and, finally, his coefficient of risk-aversion is being measured according to his investment horizon and preference.

In the phase of certainty, the financial model is built using assumptions. Among the assumptions, it is important to establish whether macro variables, such as inflation and currency exchange rate, are predictable or not. Likewise, the structure of the financial model should be determined, which should be as simple as possible: a unique spreadsheet, with annual forecasts, with as less variables as possible (usually less than 100) and for a horizon that normally spaces between five and ten years, depending on how long the business competitive advantage is supposed to last.

The prospective phase considers as its main purpose the design of the scenarios in which the business will be evaluated. It is fundamental to respect the methodology, which consists in listing all the environmental variables that cannot be controlled (strength of the environment) and in identifying those that have the highest impact on the business and those whose occurrence is highly uncertain (critical uncertainty). Among the latter group, the combinations that 
are most diversified (scenarios) and that have the highest occurrence probability should be chosen (in case of subjective probability estimation).

This way, each scenario is detailed enough to represent a feasible future and to help making a decision. There are several software that help on the selection of scenarios; Morphol, for instance, allows the identification of one or two middle options between two extremes. The recommendation is to have a total of three or four mutually exclusive or jointly exhaustive scenarios (optimistic scenario, desired scenario, actual scenario and pessimistic scenario). The idea is that any possibility is included in the designed ones.

The risk analysis phase aims to assess the total business risk for each year of the investment horizon and for each scenario. This step is crucial because it is here that the entrepreneur becomes conscious of how his cognitive biases influence his perception of the risk of the project. Similarly, this phase shows that it is not necessary to have comparable firms listed in the stock market in order to estimate the risk (myopic paradigm).

In this stage the critical variables of the project are identified, meaning the ones that have a more than proportional impact on the two output variables of the model: return over invested capital (ROIC) and free cash flow (FCF). It is realized a sensibility analysis by changing all the input variables of the financial model of $+/-10 \%$ in order to see what is their impact over the two output variables. If the impact is higher than $10 \%$, then the input variables are classified as critical since their volatility explains most of the volatility of the measures of creation of business value, otherwise they are classified as certain.

Once the critical variables are identified, they are characterized using specialized software such as Top rank or Crystal Ball. The process consists in assigning to each critical variable a known probability distribution using one of the following methods: the historic method, the expertise method or the ad-hoc method.

The first contemplates an historic series of data for each critical variable and, through a test of goodness of fit, it is identified the distribution of probability that better describes the data. The second method is the construction of a series of ordered pairs (value of the critical variable and its accumulated probability) starting from heuristic processes such as the probability wheel applied by experts. Then, with a test of goodness of fit, it is chosen the probability distribution that best suits the data. Finally, the third method assigns one of the three probability functions to the critical variables, depending on the degree of information that each variable is assumed to have: uniform distribution (there is no information apart from the range of possible values), triangular distribution (in addition, the most probable value is known) and normal distribution (also the dispersion of the critical variable is known).

Once the variables have been characterized, the critical ones are calibrated and the total business risk is calculated for each year and for each scenario through a simulation analysis. Three features are of particular importance: to use an efficient simulation algorithm (one that can achieve convergence with few interactions), to prove that convergence has been achieved for each scenario and 
to verify that the standard deviation of the return over invested capital never exceeds $100 \%$.

Convergence means that a new simulation of critical variables using the same scenario will not provide average values of the output variables that are different from the previous ones for more than one error margin and with a determined level of confidence. Software such as @Risk allow the use of efficient simulation algorithms, like the Latin Hypercubic, which permits the achievement of convergence with a fewer number of interactions than a Montecarlo simulation, due to the fact that the interactions alternate between the distribution extreme values and its values from its central part.

It is important to notice that the standard deviation of the output variable should never be more than $100 \%$ since this would imply that the entrepreneur not only risks his own capital but also the capital of someone else; a fact that is not consistent with the assumption that entrepreneurs generally start businesses counting only on their own capital.

The measures of total risk are normally the following ones:

$$
T R_{t}^{P}=\sigma_{t}^{P}(R O I C)
$$

Where:

$T R_{t}^{P}=$ total risk of project $\mathrm{P}$ at time t;

$\sigma_{t}^{P}(R O I C)=$ volatility of return over invested capital of project $\mathrm{P}$ at time $\mathrm{t}$.

$$
T R_{t}^{P}=C V_{t}^{P}=\frac{\sigma_{t}^{P}(R O I C)}{|E(R O I C)|}
$$

Where:

$T R_{t}^{P}=$ total risk of project $\mathrm{P}$ at time $\mathrm{t}$;

$C V_{t}^{P}=$ coefficient of variation of project $\mathrm{P}$ at time t.

$\sigma_{t}^{P}(R O I C)=$ volatility of return over invested capital of project $\mathrm{P}$ at time $\mathrm{t}$.

$|E(R O I C)|=$ absolute value of the expected value of the return over the invested capital.

$$
R O I C_{t}=\frac{E B I T_{t}(1-T)}{I C_{t}}
$$

Where:

$R O I C_{t}=$ return over invested capital at time t.

$E B I T_{t}=$ earnings before interest and taxes at time t.

$T=$ income tax rate.

$I C_{t}=$ invested capital at time t.

The first measure of risk is used when the dispersion of the simulated ROIC per year is symmetric, then its standard deviation is an adjusted measure. The second equation is used when there are many extreme values of the average ROIC for different years, so the coefficient of variation (CV) is employed. If the standard deviation of ROIC is higher than $100 \%$ for any of the year in any of the scenarios, the parameters of the distributions must be adjusted so that the 
new simulation will return a standard deviation that is less than $100 \%$. This is a trial and error process.

It might be thought that a project accepts any calibration of its critical variables, but that is wrong: the possible range of parameters per scenario is limited. In the optimistic scenario a critical input variable is high if it is an income and low if it is an expenditure, while in the pessimistic scenario is the opposite. Likewise, the lower degree of risk is present in the optimistic scenario while the higher in the pessimistic one. In synthesis, the aim is not to forecast exactly the total risk but to obtain a range for each year and scenario: this will make it possible to know the risk profile of the project per scenario (its temporary volatility) and to verify that the required rates of return are proportionate to the estimated risks.

Once the total business risk per year and scenario is calculated, it is necessary to estimate the required rate of return for the entrepreneur and the project value per year and scenario, with and without overconfidence. The required return without bias, for a non-diversified entrepreneur with limited wealth and the lowest risk-aversion is:

$$
E_{t}\left\lceil K s u_{t+1}\right\rceil=K_{f}^{L}+\sigma_{t+1}(R O I C)
$$

Where:

$E_{t}\left\lceil K s u_{t+1}\right\rceil=$ expected value of the required return -since the entrepreneur only has his own funds - at time t;

$K_{f}^{L}=$ risk-free return that can be obtained locally;

$R O I C=$ total business risk for each year of the explicit investment horizon and each scenario.

If the entrepreneur has a moderate overconfidence bias, his required rate of return is equal to:

$$
E_{t}\left\lceil K s u_{t+1}\right\rceil=K_{f}+S R_{t+1} \times C V_{t+1} \times E_{t}\left\{\frac{1}{(2 A+1)}\right\}
$$

Where:

$E_{t}\left\lceil K s u_{t+1}\right\rceil=$ expected value of the required return -since the entrepreneur only has his own funds - at time t;

$K_{f}=$ risk-free return that can be obtained locally;

$S R_{t+1}=$ Sharpe ratio of the business at time $\mathrm{t}+1$;

$C V_{t+1}=$ coefficient of variation at time $\mathrm{t}+1$.

$A=$ risk-aversion coefficient.

Comparing the last two equations, it results that equation (5) (which includes overconfidence) always returns smaller required returns than equation (4) (which does not include overconfidence). Therefore, there is a tendency to overestimate the business value in all the scenarios. Making both calculations helps the entrepreneur becoming conscious of the effect of the overconfidence on 
the business value. This value is obtained by using the Adjusted Preset Value (APV).

During the strategic phase, contingence's strategies are formulated to help facing the elected scenarios. In the optimistic scenario, these strategies lead the business to an expansion, while in the pessimistic scenario they help limiting the losses. Additionally, the critical variables' parameters are modified according to the strategy for each scenario and the business risk and the required return are re-calculated each time. This way it is possible to evaluate the impact of the different strategies over the value of the business.

If the entrepreneur decides to look for angel capital or private equity, he will achieve the phase of negotiation and he will have to calculate the indicators that are most commonly used by angel investors to evaluate a project:

$$
B A O=\frac{B A I(1+B A R R)^{n}}{C V^{n}}
$$

Where:

$B A O=$ Business Angel Ownership;

$B A I=$ Business Angel Investment;

$B A R R=$ Business Angel Required Return;

$C V=$ Business continuing value when angels depart.

The Business Angel Ownership is the portion of the business that they have to buy in order to obtain the agreed required return when leaving. Other metrics are:

$$
B A N S=\frac{B A O}{1-B A O} \times O S
$$

Where:

$B A N S=$ Business Angel New Shares;

$B A O=$ Business Angel Ownership;

$O S=$ Number of old shares.

$$
B A S P=\frac{B A I}{B A N S}
$$

Where:

$B A S P=$ Business Angel Share Price;

$B A I=$ Business Angel Investment;

$B A N S=$ Business Angel New Shares.

Finally, the measure that allows calculating the value of the company when angel investors leave is the Post-Money Valuation:

$$
P M V=\frac{C V_{n}}{(1+B A R R)^{n}}
$$

Where:

$P M V=$ Post-Money Valuation;

$B A R R=$ Business Angel Required Return;

$C V=$ Business continuing value when angels depart. 
The phase of negotiation culminates with the establishment of reservation points for each indicator, keeping in mind that usually angel investors never invest more than $20 \%$ of the value of the company. The idea is that the entrepreneur knows the maximum portion of the business that he will have to give in order to provide angel investors with the minimum required return in a defined period, given the amount of capital that angel investors are willing to invest. The establishment of reservation points helps reducing the gap between the evaluation made by the entrepreneur and the one made by angel investors.

\section{Application of the valuation proposal}

This section offers an application of the proposed methodology for an entrepreneur that is facing the decision of establishing a new textile company of silk production. For demonstrative purposes, it is assumed that the entrepreneur does not show any cognitive bias during the first phase of the model. The initial investment is $\$ 500,000,80 \%$ of which is destined to buy machines, $10 \%$ to working capital - which, starting from year 2, is expected to be $30 \%$ of the change in sales-, $5 \%$ to pre-operating expenses and $5 \%$ to unforeseen events.

The free cash flows (FCF) and the return over the invested capital in conditions of certainty are the followings:

Table 1: FCF and ROIC in conditions of certainty

\begin{tabular}{|c|c|c|c|}
\hline Year & $\begin{array}{c}\text { Free Cash Flows } \\
\text { (FCF) }\end{array}$ & Invested Capital (IC) & $\begin{array}{c}\text { Return orer } \\
\text { invested capital } \\
\text { (ROIC) }\end{array}$ \\
\hline 1 & $\$ 278,440.68$ & $\$ 500,000.00$ & $57 \%$ \\
\hline 2 & $\$ 286,863.98$ & $\$ 555,423.73$ & $58 \%$ \\
\hline 3 & $\$ 308,211.02$ & $\$ 610,847.46$ & $56 \%$ \\
\hline 4 & $\$ 329,558.05$ & $\$ 666,271.19$ & $55 \%$ \\
\hline 5 & $\$ 350,905.08$ & $\$ 721,694.92$ & $54 \%$ \\
\hline
\end{tabular}

Source: Own elaboration

Taking these cash flows and returns as reference, the following indicators can be calculated to financially value the venture:

Table 2: Value of the venture in conditions of certainty

\begin{tabular}{|c|c|}
\hline Financial Indicator & Value \\
\hline EV & $\$ 32,293,054.66$ \\
\hline NPV & $\$ 31,793,054.66$ \\
\hline IRR & $212 \%$ \\
\hline
\end{tabular}

Source: Own elaboration 
According to these indicators, the value of the company without debt (VU) is slightly more than $\$ 32$ million, its net present value (NPV) is almost $\$ 32$ million and the internal rate of return is $212 \%$. Consequently, the decision of starting this venture becomes highly attractive for the entrepreneur.

The target market is United States, where there is strong competition due to the Chinese products. This competition has $70 \%$ probability of getting stronger, $20 \%$ of staying the same and $10 \%$ of decreasing. Moreover, there is a $30 \%$ probability that the cotton's manufacturers strike. Therefore, it is necessary to analyze several scenarios.

With the help of Morphol and using the information of Table 3, the following scenarios are selected: pessimistic scenario (Chinese competition increases and there is a manufacturers' strike); actual scenario (Chinese competition increases and there is not a manufacturers' strike) and optimistic scenario (Chinese competition weakens and there is not a manufacturers' strike).

Table 3: Information about the strength of the environment

\begin{tabular}{|c|c|c|c|c|}
\hline $\begin{array}{c}\text { Environment } \\
\text { Strength }\end{array}$ & $\begin{array}{c}\text { Pessimistic } \\
\text { Scenario }\end{array}$ & $\begin{array}{c}\text { Actual } \\
\text { Scenario }\end{array}$ & $\begin{array}{c}\text { Optimistic } \\
\text { Scenario }\end{array}$ & Scope \\
\hline $\begin{array}{c}\text { Chinese } \\
\text { Competition }\end{array}$ & It grows & It maintains & It decreases & International \\
\hline Probability & $70 \%$ & $20 \%$ & $10 \%$ & - \\
\hline $\begin{array}{c}\text { Manufacturer } \\
\text { s' Strike }\end{array}$ & It happens & $\begin{array}{c}\text { It does not } \\
\text { happen }\end{array}$ & & Industry \\
\hline Probability & $30 \%$ & $70 \%$ & & - \\
\hline
\end{tabular}

Source: Own elaboration

Once constructed the scenarios, the following step is to determine and characterize the critical variables of the project. A sensitivity analysis is performed through the software Top Rank and, as a result, three critical variables are proven to have a significant effect: the sale price per meter, for which a variation of $+/-10 \%$ affects the first-year free cash flow up to $93 \%$; the thread's price per $\mathrm{kg}$, for which a variation of $+/-10 \%$ affects the first-year free cash flow by almost $72 \%$; and, finally, the sales per meter, for which a variation of $+/-10 \%$ affects the first-year free cash flow up to $15.3 \%$ (Table 4 ).

Table 4: Identification of the critical variables for the first-year FCF

\begin{tabular}{|c|c|c|c|c|c|c|c|c|}
\hline \multirow{3}{*}{ Position } & \multirow{3}{*}{ Variable } & \multicolumn{3}{|c|}{ Minimum } & \multicolumn{3}{|c|}{ Maximum } & \multirow[b]{2}{*}{ Input } \\
\hline & & \multicolumn{2}{|c|}{ Output } & \multirow{2}{*}{$\begin{array}{l}\text { Input } \\
\text { Value }\end{array}$} & \multicolumn{2}{|c|}{ Output } & \multirow{2}{*}{$\begin{array}{l}\text { Input } \\
\text { Value }\end{array}$} & \\
\hline & & Value & Change (\%) & & Value & Change (\%) & & Basic Value \\
\hline 1 & $\begin{array}{l}\text { Sale price per } \\
\text { meter }\end{array}$ & 19,797 & $-92.89 \%$ & 3.924 & 537,085 & $92.89 \%$ & 4.796 & 4.36 \\
\hline
\end{tabular}




\begin{tabular}{|c|c|c|c|c|c|c|c|c|}
\hline \multirow{3}{*}{ Position } & \multirow{3}{*}{ Variable } & \multicolumn{3}{|c|}{ Minimum } & \multicolumn{3}{|c|}{ Maximum } & \multirow[b]{2}{*}{ Input } \\
\hline & & \multicolumn{2}{|c|}{ Output } & \multirow{2}{*}{$\begin{array}{l}\text { Input } \\
\text { Value }\end{array}$} & \multicolumn{2}{|c|}{ Output } & \multirow{2}{*}{$\begin{array}{l}\text { Input } \\
\text { Value }\end{array}$} & \\
\hline & & Value & Change (\%) & & Value & Change (\%) & & Basic Value \\
\hline 2 & $\begin{array}{c}\text { Price per } \mathrm{kg} \text { of } \\
\text { thread }\end{array}$ & 78,241 & $-71.90 \%$ & 2.42 & 478,641 & $71.90 \%$ & 1.98 & 2.2 \\
\hline 3 & Sales per meter & 235,747 & $-15.33 \%$ & 900,000 & 321,135 & $15.33 \%$ & $1,100,000$ & $1,000,000$ \\
\hline 4 & $\begin{array}{c}\text { Sales per oil } \\
\text { galleon }\end{array}$ & 268,641 & $-3.52 \%$ & 1.1 & 288,241 & $3.52 \%$ & 0.9 & 1 \\
\hline 5 & Direct labor & 273,541 & $-1.76 \%$ & 77,000 & 283,341 & $1.76 \%$ & 63,000 & 70,000 \\
\hline
\end{tabular}

Source: Own elaboration

Notice that the price per oil galleon and the direct labor do not exceed $10 \%$ of impact over the first-year free cash flow and are, therefore, considered in conditions of certainty.

To characterize the critical variables it is used the ad-hoc method, which assigns to each critical variable one of the following distributions: uniform, triangular and normal. Once the critical variables have been characterized, the corresponding risk is analyzed and the total risk, the required return and the business value are calculated for each scenario from the perspective of the entrepreneur (Table 6).

In the pessimistic scenario (i.e. stronger competition from China and manufacturers' strike), the project returns a negative internal rate of return with a negative net present value of more than $\$ 340000$, with a required return by the entrepreneur of $18 \%$. In the actual scenario, the internal rate of return is $12 \%$ and the average required return is $14 \%$. In the optimistic scenario, the internal rate of return is estimated to be $72 \%$, being $11 \%$ the average required return. Notice that even in the optimistic scenario the project offers a maximum of almost $\$ 2.5$ million instead of the $\$ 32$ million that were estimated in conditions of certainty.

Table 5: Characterization of critical variables for each scenario

\begin{tabular}{|c|c|c|c|c|c|}
\hline $\begin{array}{c}\text { Critical } \\
\text { Variable }\end{array}$ & Distribution & Minimum & $\begin{array}{c}\text { Most } \\
\text { Probable } \\
\text { Value }\end{array}$ & Maximum & $\begin{array}{c}\text { Standard } \\
\text { Deviation }\end{array}$ \\
\hline \multicolumn{7}{|c|}{ Pessimistic Scenario } \\
\hline $\begin{array}{c}\text { Sales per } \\
\text { meter }\end{array}$ & Normal & - & 300,000 & - & $7 \%$ \\
\hline $\begin{array}{c}\text { Price per } \\
\text { meter (USD) }\end{array}$ & Uniform & $-8 \%$ & 3.69 & $8 \%$ & \\
\hline $\begin{array}{c}\text { Price per kg } \\
\text { of thread } \\
\text { (USD) }\end{array}$ & Triangular & $-4 \%$ & 2.5 & $4 \%$ & \\
\hline
\end{tabular}




\begin{tabular}{|c|c|c|c|c|c|}
\hline $\begin{array}{c}\text { Critical } \\
\text { Variable }\end{array}$ & Distribution & Minimum $\begin{array}{c}\text { Most } \\
\text { Probable } \\
\text { Value }\end{array}$ & Maximum & $\begin{array}{c}\text { Standard } \\
\text { Deviation }\end{array}$ \\
\hline \multicolumn{5}{|c|}{ Actual Scenario } \\
\hline $\begin{array}{c}\text { Sales per } \\
\text { meter }\end{array}$ & Normal & - & 600,000 & - & $6 \%$ \\
\hline $\begin{array}{c}\text { Price per } \\
\text { meter (USD) }\end{array}$ & Uniform & $-6 \%$ & 4,36 & $6 \%$ & - \\
\hline $\begin{array}{c}\text { Price per kg } \\
\text { of thread } \\
\text { (USD) }\end{array}$ & Triangular & $-3 \%$ & 2.2 & $3 \%$ & \\
\hline \multicolumn{1}{|c|}{$\begin{array}{c}\text { Optimistic Scenario } \\
\text { meter }\end{array}$} & Normal & - & $1,200,000$ & - & $5 \%$ \\
\hline $\begin{array}{c}\text { Price per } \\
\text { meter (USD) }\end{array}$ & Uniform & $-4 \%$ & 4,5 & $5 \%$ & - \\
\hline $\begin{array}{c}\text { Price per kg } \\
\text { of thread } \\
\text { (USD) }\end{array}$ & Triangular & $-2 \%$ & 2,0 & $2 \%$ & - \\
\hline
\end{tabular}

Source: Own elaboration

Table 6: Valuation of the venture for each scenario (Entrepreneur's point of view)

\begin{tabular}{|c|c|c|c|}
\multicolumn{1}{c}{ Indicator } & $\begin{array}{c}\text { Pessimistic } \\
\text { Scenario }\end{array}$ & $\begin{array}{c}\text { Actual } \\
\text { Scenario }\end{array}$ & $\begin{array}{c}\text { Optimistic } \\
\text { Scenario }\end{array}$ \\
\hline $\begin{array}{c}\text { Average required } \\
\text { return }\end{array}$ & $18 \%$ & $14 \%$ & $11 \%$ \\
\hline $\begin{array}{c}\text { Internal rate of } \\
\text { return }\end{array}$ & $-41 \%$ & $12 \%$ & $72 \%$ \\
\hline Present value & $\$ 129,274$ & $\$ 734,274$ & $\$ 1,638,364$ \\
\hline Net present value & $-\$ 341,667$ & $\$ 718,982$ & $\$ 2,441,344$ \\
\hline
\end{tabular}

Source: Own elaboration

On the other side, if the entrepreneur invites angel investors, considering that they would stay for five years and that, on average, their required return is $20 \%$, the result of the evaluation from their point of view will be the following: 
Table 7: Valuation of the venture for each scenario (Angel investor's point of view)

\begin{tabular}{|c|c|c|c|}
\hline Indicator & \multicolumn{1}{c}{$\begin{array}{c}\text { Pessimistic } \\
\text { Scenario }\end{array}$} & $\begin{array}{c}\text { Actual } \\
\text { Scenario }\end{array}$ & $\begin{array}{c}\text { Optimistic } \\
\text { Scenario }\end{array}$ \\
\hline BAI & - & $\$ 100,000$ & $\$ 300,000$ \\
\hline BAO & $116 \%$ & $18 \%$ & $15 \%$ \\
\hline BASP & - & $\$ 45$ & $\$ 123$ \\
\hline $\begin{array}{c}\text { Post-money } \\
\text { valuation }\end{array}$ & - & $\$ 552,349$ & $\$ 1,333,652$ \\
\hline
\end{tabular}

Source: Own elaboration

Table 7 shows that in the worst-case scenario the angel investors do not invest in the business, while in the best one they can invest up to $\$ 300,000$. In the optimistic scenario they need to buy $15 \%$ of the venture in order to obtain a $20 \%$ return in five years, while in the pessimistic one they need to buy $116 \%$. The analysis shows that the project is interesting whenever contingence's strategies are established to face each scenario, especially the pessimistic one.

Table 8 offers the matrix of contingence's strategies: for each considered scenario it is, in fact, possible to define contingence's strategies to face it. In the pessimistic scenario, one of the most relevant strategies is the replacement of manufacturers in order to achieve better negotiation terms. Additionally, other strategies are to position the company with American companies through strategic alliances, to look for new markets in Latin America and to increase the loyalty of the current clients.

Table 8: Matrix of contingence's strategies

\begin{tabular}{|c|c|c|c|}
\hline Scenario & $\begin{array}{c}\text { Pessimistic Scenario } \\
\text { Chinese competition } \\
\text { strengthens and } \\
\text { manufacturer's strike }\end{array}$ & $\begin{array}{c}\text { Actual Scenario } \\
\text { Chinese competition } \\
\text { stays the same, there is } \\
\text { no strike }\end{array}$ & $\begin{array}{c}\text { Optimistic Scenario } \\
\text { Chinese competition } \\
\text { weakens, there is no } \\
\text { manufacturer strike }\end{array}$ \\
\hline $\begin{array}{c}\text { Contingence's } \\
\text { Strategy }\end{array}$ & $\begin{array}{c}\text { Manufacturers' } \\
\text { replacement } \\
\text { productivity and } \\
\text { decrease of } \\
\text { production's costs to } \\
\text { get a more competitive } \\
\text { price margin }\end{array}$ & $\begin{array}{c}\text { Negotiation with } \\
\text { thread's suppliers to } \\
\text { decrease the price per } \\
\mathrm{kg}\end{array}$ \\
\hline
\end{tabular}




\begin{tabular}{|c|c|c|c|}
\hline \multirow{4}{*}{ Scenario } & $\begin{array}{c}\text { Pessimistic Scenario } \\
\text { Chinese competition } \\
\text { strengthens and } \\
\text { manufacturers strike }\end{array}$ & $\begin{array}{c}\text { Actual Scenario } \\
\text { Chinese competition } \\
\text { stays the same, there is } \\
\text { no strike }\end{array}$ & $\begin{array}{c}\text { Optimistic Scenario } \\
\text { Chinese competition } \\
\text { weakens, there is no } \\
\text { manufacturer strike }\end{array}$ \\
\hline \multirow{5}{*}{$\begin{array}{c}\text { Contingence's } \\
\text { Strategy }\end{array}$} & $\begin{array}{c}\text { Sales' increase trough } \\
\text { a positioning campaign } \\
\text { in the US market }\end{array}$ & $\begin{array}{c}\text { Negotiation with } \\
\text { thread's suppliers to } \\
\text { decrease the price per } \\
\mathrm{kg}\end{array}$ & $\begin{array}{c}\text { Brand recognition's } \\
\text { strategy }\end{array}$ \\
\cline { 2 - 5 } & $\begin{array}{c}\text { Exploration of new } \\
\text { markets in Latin } \\
\text { America }\end{array}$ & $\begin{array}{c}\text { Programs of public } \\
\text { incentives for the } \\
\text { products' exportation }\end{array}$ & $\begin{array}{c}\text { Market expansion } \\
\text { through product } \\
\text { diversification }\end{array}$ \\
\cline { 2 - 5 } & $\begin{array}{c}\text { Development of a } \\
\text { loyalty program for } \\
\text { actual clients }\end{array}$ & $\begin{array}{c}\text { Market penetration } \\
\text { strategy }\end{array}$ & $\begin{array}{c}\text { Strategic alliances with } \\
\text { other textile's products }\end{array}$ \\
\hline
\end{tabular}

Source: Own elaboration

Finally, notice that, based on the realized calculations, it is possible to define the entrepreneur's reservation point. Assuming that the strategies allow the conversion of the pessimistic scenario to one closer to the actual, the entrepreneur cannot accept a sale price per stock that is less than $\$ 45$ and a capital contribution less than $\$ 100,000$ (Table 7 ). Moreover, it is possible to test different required return and terms for the angel investors.

\section{Conclusion}

The decision-making process of an entrepreneur is mainly based on cognitive aspects associated to the attractiveness and perceived riskiness of the business opportunity, as well as on his impression of his own skills and knowledge to successfully conduct the creation and management of the firm. Nevertheless, the presence of biases limits the entrepreneur's vision of less favorable scenarios that he could potentially face and, by ignoring them, the entrepreneur starts new business with high probability of bankruptcy in their first years of operations.

In front of such a situation, the methodology proposed by the present study allows the entrepreneur not only to be conscious of his own biases and of their potential impact on the project but also to conduct a multidimensional valuation of the project, so that he could base his decision of undertaking or not the project depending on how proper and feasible are the strategies formulated for each scenario. This grants a passage from a valuation based only on the value on its own to one that considers also the behavioral features of the entrepreneur.

Additionally, the methodology proposed shows that it is possible to evaluate ventures even when there are not comparable companies and, precisely, in the most common case, which is when entrepreneurs are not diversified, have low resources and act as non-risk-averse even without cognitive biases.

Although the methodology is widely applicable, it is important to point out that it must be used cautiously since in each scenario the valuator is exposed to 
the GIGO principle (Garbage In, Garbage Out), which implies that the values assigned to the parameters of the critical variables should be plausible and reasonable in order to obtain an achievable value.

Finally, the methodology presents an alternative form to begin a negotiation process between the entrepreneur and the angel investors, making it possible to bridge the gap that usually exists between their two ways of valuing a venture.

Future research should consider the application of an empirical study in different kind of startups to proof the usefulness and real potential of the proposed methodology against others. This empirical study must be conducted through different stages of the incubated new ventures.

\section{References}

Acosta-Veliz, M. M., Villacís-Aveiga, W. H.,and Jiménez-Cercado, M. E. (2017). Factores que conforman la intención emprendedora de estudiantes de la Universidad de Guayaquil. Dominio de las Ciencias, 3(3), pp. 1116-1146.

Audretsch, D. B., Bönte, W., and Keilbach, M. (2008). Entrepreneurship capital and its impact on knowledge diffusion and economic performance. Journal of business venturing, 23(6), pp. 687-698.

Barba-Sánchez, V., and Atienza-Sahuquillo, C. (2012). Entrepreneurial behavior: Impact of motivation factors on decision to create a new venture. Investigaciones Europeas de Dirección y Economía de la Empresa, 18(2), pp. 132-138.

Barba-Sánchez, V. and Atienza-Sahuquillo, C. (2017). Entrepreneurial motivation and selfemployment: evidence from expectancy theory. International Entrepreneurship and Management Journal, pp. 1-19.

Baron, R. A., Mueller, B. A., and Wolfe, M. T. (2016). Self-efficacy and entrepreneurs' adoption of unattainable goals: The restraining effects of self-control. Journal of Business Venturing, 31(1), pp. 55-71.

Bonnet, J., Brau, T., Cussy, P., and Auray, S. (2008). The entrepreneurial decision-making: a complex choice where taste, risk, endowments, necessity, opportunity, personals traits and behaviour matter (No. 200801). Center for Research in Economics and Management (CREM), University of Rennes 1, University of Caen and CNRS.

Brockhaus, R. H. (1980). Risk taking propensity of entrepreneurs. Academy of management Journal, 23(3), pp. 509-520.

Busenitz, L. W., and Barney, J. B. (1997). Differences between entrepreneurs and managers in large organizations: Biases and heuristics in strategic decision-making. Journal of business venturing, 12(1), pp. 9-30.

Busenitz, L. W., and Lau, C. M. (1996). A cross-cultural cognitive model of new venture creation. Entrepreneurship: Theory and Practice, 20(4), pp. 25-40.

Chen, S. C., and Elston, J. A. (2013). Entrepreneurial motives and characteristics: An analysis of small restaurant owners. International Journal of Hospitality Management, 35, 294305.

Espíritu-Olmos, R., and Sastre-Castillo, M. A. (2015). Personality traits versus work values: Comparing psychological theories on entrepreneurial intention. Journal of Business Research, 68(7), pp. 1595-1598.

Forbes, D. P. (2005). Are some entrepreneurs more overconfident than others?. Journal of business venturing, 20(5), pp. 623-640.

Gudmundsson, S. V., and Lechner, C. (2013). Cognitive biases, organization, and entrepreneurial firm survival. European Management Journal, 31(3), pp. 278-294.

INEGI (2014), Difusión de la Encuesta Nacional sobre Productividad y Competitividad de las Micro, Pequeñas y Medianas Empresas (ENAPROCE 2015). INEGI, pp. 15-17. 
Fernández, Q., Miriam, G., Nina, A., Dante, V., and De la Cruz Fernández, G. M. (2017). Iniciativa del emprendimiento en los entornos rurales: un estudio de los factores culturales. Revista Venezolana de Gerencia, 22(78), pp. 191-209.

Kahneman, D., and Lovallo, D. (1993). Timid choices and bold forecasts: A cognitive perspective on risk taking. Management science, 39(1), pp. 17-31.

Koellinger, P., Minniti, M., and Schade, C. (2007). "I think I can, I think I can": Overconfidence and entrepreneurial behavior. Journal of economic psychology, 28(4), pp. 502-527.

Lin, J. B., and Herbst, A. F. (2003). Valuation of a startup business with pending patent using real options. El Paso, TX.

Martinkutè-Kaulienè, R., Stankevičienè, J., and Žinytė, S. (2013). Option pricing using Monte Carlo simulation. Journal of Security Sustainability Issues, 2(4).

McGee, J. E., Peterson, M., Mueller, S. L., and Sequeira, J. M. (2009). Entrepreneurial selfefficacy: refining the measure. Entrepreneurship theory and Practice, 33(4), pp. 965-988.

Millán, F. J., Jaramillo, M. J., and Chávez, M. A. P. (2017). Factores que inciden en la intención emprendedora de estudiantes del Centro Universitario Temascaltepec. Revista Venezolana de Gerencia, 22(78), pp. 210-231.

Minniti, M., and Nardone, C. (2007). Being in someone else's shoes: the role of gender in nascent entrepreneurship. Small Business Economics, 28(2-3), pp. 223-238.

Nouri, P., Imanipour, N., Talebi, K., and Zali, M. (2017). Heuristics and Biases in Entrepreneurial Marketing: Some New Insights. International Journal of Entrepreneurship, 21(3).

Palich, L. E., and Bagby, D. R. (1995). Using cognitive theory to explain entrepreneurial risk-taking: Challenging conventional wisdom. Journal of business venturing, 10(6), pp. 425-438.

Shinnar, R. S., Young, C. A. (2008). Hispanic immigrant entrepreneurs in the Las Vegas metropolitan area: motivations for entry into and outcomes of self-employment. Journal of Small Business Management, 46(2), pp. 242-262.

Simon, M., Houghton, S. M., and Aquino, K. (2000). Cognitive biases, risk perception, and venture formation: How individuals decide to start companies. Journal of business venturing, 15(2), pp. 113-134.

Zhang, S. X., and Cueto, J. (2017). The study of bias in entrepreneurship. Entrepreneurship Theory and Practice, 41(3), pp. 419-454. 
440 Nueva Época REMEF (The Mexican Journal of Economics and Finance) 